\title{
Influence of Air Mass Origin on Aerosol Properties at a Remote Michigan Forest Site
}

\author{
T. M. VanReken ${ }^{1 *}$, G. R. Mwaniki ${ }^{1,2}$, H.W. Wallace ${ }^{1,3}$, S. N. Pressley ${ }^{1}$, \\ M.H. Erickson ${ }^{1,4}$, B.T. Jobson ${ }^{1}$, and B. K. Lamb ${ }^{1}$ \\ ${ }^{1}$ Laboratory for Atmospheric Research, Dept. of Civil \& Environmental Engineering, \\ Washington State University, Pullman, Washington, USA \\ ${ }^{2}$ Now with the African Centre for Technology Studies, Nairobi, Kenya \\ ${ }^{3}$ Now with Dept. of Civil \& Environmental Engineering, Rice University, Houston, Texas, USA \\ ${ }^{4}$ Now with Houston Advanced Research Center, Houston, Texas, USA \\ * Corresponding Author: vanreken@wsu.edu \\ KEYWORDS: Aerosol, Trajectory Analysis, Hygroscopicity
}

\section{ABSTRACT}

The northern Great Lakes region of North America is a large, relatively pristine area. To date, there has only been limited study of the atmospheric aerosol in this region. During summer 2009, a detailed characterization of the atmospheric aerosol was conducted at the University of Michigan Biological Station (UMBS) as part of the Community Atmosphere-Biosphere Interactions Experiment (CABINEX). Measurements included particle size distribution, water-soluble composition, and CCN activity. Aerosol properties were strongly dependent on the origin of the air masses reaching the site. For $\sim 60 \%$ of the study period, air was transported from sparsely populated regions to the northwest. During these times aerosol loadings were low, with mean number and volume concentrations of $1,630 \mathrm{~cm}^{-3}$ and $1.91 \mu^{3}$ $\mathrm{cm}^{-3}$, respectively. The aerosol during clean periods was dominated by organics, and exhibited low hygroscopicities (mean $\kappa=18$ at $s=0.3 \%$ ). When air was from more populated regions to the east and south ( $29 \%$ of the time), aerosol properties reflected a stronger anthropogenic influence, with $85 \%$ greater particle number concentrations, 2.5 times greater aerosol volume, six times more sulfate mass, and increased hygroscopicity (mean $\kappa=0.24$ at $s=0.3 \%)$. These trends are have the potential to influence forest-atmosphere interactions and should be targeted for future study. 


\section{Introduction}

Atmospheric particles have many impacts within the earth-atmosphere system, including effects on ecosystem function. Aerosols scatter and absorb incoming solar radiation, changing the balance of direct and diffuse radiation, which leads to changes in plant carbon and water exchange (Steiner et al., 2013). Particles affect cloud processes and can modify precipitation cycles (Kaufman et al., 2005). Atmospheric deposition can be a major source of nutrient replenishment, a key requirement for ecosystem health, but the type or amount of material deposited can also have negative impacts, including acid deposition and excessive nitrogen loads (Fowler et al., 2009). There is evidence that there are air pollution-related feedbacks from the terrestrial biosphere back to the atmosphere. The terrestrial biosphere is also a major emission source of biogenic volatile organic compounds (VOCs) that react in the atmosphere to form secondary organic aerosol (SOA). More than two-thirds of global VOC emissions are estimated to be from biogenic sources (Guenther et al., 2006), and biogenic SOA is a major contributor to the global aerosol burden (Tsigaridis and Kanakidou, 2007). Anthropogenic pollution, particularly ozone, can influence the processes that lead to SOA production from biogenic VOCs by changing the amount and composition of biogenic emissions by inducing plant stress responses (Carslaw et al., 2010). To date, pollution-induced changes to biogenic VOC emissions have not been studied in ambient environments, and biogenic VOC emission models do not yet account for pollution stress. The phenomena are expected to be difficult to isolate, but one step is to more fully study the nature of episodic pollution events in generally clean environments.

The northern Great Lakes region of North America, with extensive mixed-hardwood forests, is one area where significant variability in air quality occurs. To the south and east of this region lie heavily populated parts of the United States and Canada. To the west and north are remote environments with much less human activity. Despite the region's size, to date there have few aerosol studies conducted in this region, but they have suggested that aerosols, like many trace gas pollutants, exhibit strong variability associated with meteorological conditions. Sheesley et al. (2004) analyzed aerosol composition of samples collected at a remote site in Michigan's upper peninsula in the United States. They found that there was strong, patterned variability in the organic aerosol composition, and found that this variability was linked to the air mass origin region. In a comparison of five sites in southern Ontario, Canada, Jeong et al. (2010) found that most new particle events occurred when air arrived at the sites from cooler, cleaner, and drier regions to the north, while non-event days were 
usually associated with air arriving from areas with significant anthropogenic emissions. Slowik et al. (2010) measured aerosol properties at a forested site in southern Ontario that was at times exposed to either pristine atmospheric conditions or the Toronto urban outflow. When urban air impacted the site, total aerosol concentrations increased substantially, with much more sulfate, and an organic aerosol resembling combustion emissions. Air from cleaner regions to the north still had significant organic aerosol, but with characteristics indicative of biogenic SOA.

The Program for Research on Oxidants PHotochemistry, Emissions and Transport (PROPHET) site at the University of Michigan Biological Station (UMBS) is a forested atmospheric chemistry research station located in the northern part of Michigan's lower peninsula in the United States (Carroll et al., 2001). The site is located within a temperate mixed-deciduous forest representative of a large region of the north central United States and south central Canada. The surrounding area is only sparsely populated for several hundred kilometers in the predominant upwind direction (north and west), such that the anthropogenic influences on the site's atmospheric environment are often minimal. However, to the south and east there are regions of high anthropogenic activity, and previous work has indicated that air masses originating from those directions impact the site roughly $24 \%$ of the time during summer (Cooper et al., 2001).

Virtually no aerosol measurements had been made at the PROPHET site until the Community Atmosphere-Biosphere Interactions Experiment (CABINEX) in summer 2009 (an exception is the work of Delia (2004), who made aerosol composition measurements at PROPHET as part of her Ph.D. dissertation research). CABINEX was a concerted effort to study aerosol properties at PROPHET, and has resulted in several studies highlighting the processes that contribute to particle concentrations in the region. Kanawade et al. (2011) examined new particle formation during the study, focusing on the role of isoprene in suppressing such events. Slade et al. (2010) observed elevated concentrations of ultrafine particles near the surface of the Great Lakes upwind of PROPHET- a mode containing $10^{2}$ $10^{3}$ particles $\mathrm{cm}^{-3}$ was observed when surface wind speeds exceeded $\sim 2 \mathrm{~m} \mathrm{~s}^{-1}$. They concluded that these particles were emitted due to wind-driven processes at the lake surface, a phenomenon that had not been previously reported. The potential impacts of this newly discovered source were later evaluated by Chung et al. (2011), who found that the mechanism could enhance particle number concentrations by $20 \%$ in the remote northern Great Lakes region and $5 \%$ over other parts of the Great Lakes. 
In this paper, we use the combined aerosol and trace gas data available from CABINEX to further characterize the aerosol physical and chemical properties at PROPHET, focusing on how varying degrees of anthropogenic influence affect aerosols in the region. We base the analysis on the extensive set of observations made during CABINEX, including the particle size distribution, the water-soluble composition, and $\mathrm{CCN}$ concentrations. We examine the dependence of the aerosol properties and related trace gas concentrations on air mass history and compare these results to previous meteorological analyses conducted at the PROPHET site. We also estimate the aerosol hygroscopicity parameter, $\kappa$, which quantifies the tendency of particles to take up water. These analyses provide a basis for understanding the nature atmospheric aerosol in the temperate forests of north-central North America, and are a foundation for future examinations the interactions of anthropogenic pollution, natural aerosol sources, and Earth system processes in a changing world.

\section{Measurements}

CABINEX was conducted from 1 July to 8 August 2009 at the PROPHET facility at UMBS. PROPHET is located in a successional mixed deciduous forest near the northern tip

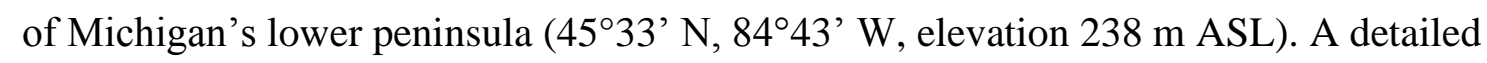
description of the site and its characteristics is provided by Carroll et al. (2001). The forest at the time was dominated by aspen $(\sim 60 \%)$, mixed with an increasing presence northern hardwoods such as maple and beech $(\sim 17 \%)$, and pines $(\sim 13 \%)$ (Bergen and Dronova, 2007). As the forest succession proceeds, emissions of biogenic VOCs will transition from the current isoprene-dominant regime to one more influenced by monoterpenes (Pressley et al., 2005; Bergen and Dronova, 2007; Toma and Bertman, 2012). The forest has a mean canopy height of $22.5 \mathrm{~m}$ and an average tree age of $\sim 90$ years. During CABINEX, aerosol data were obtained at three levels through the canopy: above-canopy (31.4 $\mathrm{m}$ above the ground), mid-canopy (20.6 m) and in the understory $(5 \mathrm{~m})$. This study concentrates on the understory aerosol measurements, which were the most extensive. While gradients existed at times between the above-canopy and understory environments, previous analysis shows substantial coupling (Bryan et al., 2012; Steiner et al., 2011), suggesting that the understory conditions reported here will be generally similar to the above-canopy conditions.

The understory aerosol sampling inlets were located on the Washington State University (WSU) Mobile Atmospheric Chemistry Laboratory (MACL). The aerosol inlet was a $15 \mathrm{~mm}$ internal diameter copper tube; a vacuum pump pulled a sample flow of $30 \mathrm{~L}$ 
$130 \mathrm{~min}^{-1}$ through this inlet into the climate-controlled MACL. Once inside, the sample flow was

131 split among the several aerosol instruments, including a scanning mobility particle sizer

132 (SMPS) (Mwaniki et al., 2014), a particle-into-liquid sampler (PILS) (Orsini et al., 2003),

133 and a cloud condensation nuclei counter (CCNc) (Roberts and Nenes, 2005). Descriptions of

134 these measurements are included in the supplementary material. All data reported here have

135 been hourly-averaged and are compared using the same time basis with the exception of the

136 PILS water-soluble aerosol composition measurements, which are based on two-hour

137 samples. Data were collected from 7 July to 8 August 2009; however, all data from the

138 understory aerosol inlet for 13-18 July were contaminated due to a leak and have been

139 removed from the data set.

\section{3. Analysis}

\section{$141 \quad 3.1$. Estimated Hygroscopicity}

142 The Köhler model predicts aerosol hygroscopic behavior, including CCN activity,

143 based on the size of a particle and the amount of soluble material present (Seinfeld and

144 Pandis, 2006). The model can be directly applied for inorganic particles, but for aerosol with

145 significant organic fractions the complexity of the composition limits its effectiveness. Petters

146 and Kreidenweis (2007) addressed this limitation by recasting water uptake behavior as a

147 function of a hygroscopicity parameter, $\kappa$, expressed in terms of the water activity and the

148 volume contribution of solute to a solution droplet. The hygroscopicity parameter has proved

149 valuable and is now widely used to characterize the water uptake of single-component

150 aerosols and of complex chemical mixtures.

151 The hygroscopicity parameter of the aerosol sampled during CABINEX was

152 estimated by comparing the measured $\mathrm{CCN}$ concentrations to the particle size distribution,

153 following an approach used previously by Roberts et al. (2010). The goal was to determine an

154 equivalent dry activation diameter, $d_{\mathrm{dry}, \text { eq }}$, for each CCN observation and then use the

155 instrument supersaturation $(s)$ and $d_{\mathrm{dry}, \text { eq }}$ to estimate $\kappa$. Details of the calculation are provided

156 in the supplementary material. This analysis implicitly assumes that the aerosol is perfectly

157 internally mixed. This is unlikely to be strictly true, potentially leading to an overestimation

158 of $\kappa$ for some particles. However new particle formation events were rare during CABINEX

159 and that the observed aerosol was nearly always unimodal; given these characteristics we feel

160 that the uniform internal mixture was a reasonable assumption for this study. 


\subsection{Air Mass Trajectory Analysis}

The goal of this analysis was to evaluate what source regions were impacting the PROPHET site during CABINEX, and to link source regions to observed aerosol and trace gas concentrations. We applied the residence time probability analysis described by Ashbaugh et al. (1985). Robinson et al. (2011) also applied this approach recently and extended it to include mean value maps, which associate an observed value at the central measurement point with the back trajectory corresponding to that same observation time. Details of these calculations are included in the supplementary material. While these approaches are not sufficient for isolating sources, they are useful for assessing general patterns in the characterization of air masses reaching the observation site.

Following the approach of Robinson et al. (2011), for this analysis we have generated two-day back trajectories, one for each hour during the CABINEX study period, with hourly time resolution along the trajectories. The region surrounding the sampling site was divided into a $0.25^{\circ} \times 0.25^{\circ}$ grid and the back trajectories were used to build the spatial histogram required for the analysis. Two-day back trajectories were used because that duration is sufficient for providing a clear indication of the origin region for air masses reaching the PROPHET site, and because beyond that time chemical and deposition processes have a greater influence on the air mass making source assessment by residence time probability approaches less reliable (Kabashnikov et al., 2011). The back trajectories were obtained using the Hybrid Single Particle Lagrangian Integrated Trajectory Model (HYSPLIT) (Draxler and Rolph, 2013). 48-hour back trajectories were calculated for each hour starting at 00:00 on 7 July 2009 and continuing to 13:00 on 9 August 2009. Each trajectory was initiated at the PROPHET site from a point $30 \mathrm{~m}$ above ground level. Back trajectories were calculated using gridded meteorological data from the 40-km Eta Data Assimilation System (EDAS40) archive.

The availability of back trajectories associated with each hourly-averaged observation also allows for observations to be classified and averaged by source region. For this study, we chose a simple classification scheme, using a representative point along a back trajectory and calculating the bearing between the observation site and that point. If the bearing fell in the right range, that trajectory and the associated observations were treated as part of that source region class. For the CABINEX analysis, we chose to use the trajectory points 24 hours prior to reaching the PROPHET tower as the set of representative points for this analysis. Although 
193

194

195

196

197

198

199

200

201

202

203

204

205

206

207

208

209

210

211

212

213

214

215

216

217

simple, this approach proved reliable in classifying air masses into statistically distinct groups with respect to the trace gas pollutant and aerosol properties.

\section{Results}

\subsection{Air Mass Origin}

In their previous study of the air pollution temporal patterns at PROPHET, Cooper et al. (2001) found two predominant air flow regimes that influenced pollutant levels. When the flow at PROPHET was northerly, originating from regions that are sparsely populated and dominated by forests, then the air reaching the site was relatively unpolluted. In contrast, when the flow was southerly, pollutant concentrations were significantly higher. This is consistent with the higher anthropogenic emissions to the south, a more densely populated region that includes several large cities and industries around Chicago, Detroit, and Cleveland. During the period described by Cooper et al. (2001), six weeks during summer 1998, northerly transport occurred $44 \%$ of the time, and southerly transport $24 \%$ of the time; the remaining $32 \%$ were transitional periods. They suggested that the dominance of northerly flow during their study period was atypical, but not exceptionally so.


Figure 1: (a) Air mass residence time probability map for the CABINEX period based on 48hour HYSPLIT back trajectories. The pink cross represents the measurement site. Probabilities are on a linear relative scale, normalized to the maximum probability in the domain. (b) Monthly-averaged tropospheric column $\mathrm{NO}_{2}$ concentrations for the region, derived from OMI. Regions of high concentration are indicative of high anthropogenic emissions. prevailing meteorology in 2009 was similar, but not identical, to what was observed in 1998 
218 by Cooper et al. (2001). The importance of the air mass origin region is clear when the

219 residence time probability map is compared to a map showing regions of high anthropogenic

220 emissions. Figure $1 \mathrm{~b}$ show the monthly-averaged tropospheric column $\mathrm{NO}_{2}$ concentrations

221 for July 2009, retrieved from the Ozone Monitoring Instrument (OMI) on the NASA Aura

222 satellite. Overall, the lightly populated regions of the northern Great Lakes and Michigan's

223 upper peninsula had the greatest influence on the air reaching the site, but frequently air

224 masses also reached PROPHET from much more heavily populated areas to the south and

225 east. To quantify these influences, we identified two source regions for further analysis. A

226 'clean' regime spanning westerly to northerly flows $\left(255-375^{\circ}\right)$ included $60 \%$ of trajectories

227 (486 of 806 total), based on the air mass's bearing relative to PROPHET 24 hours prior to

228 reaching the site. Another $29 \%$ of trajectories (236 of 806), originating from easterly to

229 southwesterly directions $\left(90-240^{\circ}\right)$, were grouped as an 'anthropogenically-impacted' regime.

230 The remaining $\sim 10 \%$ of trajectories were transitional and were not included in the source-

231 origin analysis. Unlike in the 1998 study, during CABINEX there was almost no impact from

232 regions to the northeast of the PROPHET site. As shown in Figure 2, the alternating influence

233 of clean and anthropogenically-impacted air was not limited to one or a few occurrences.

234 Rather, there were 15 instances where the bearing of origin fully changed from one category

235 to the other. These periods were as short as 7 hours and as long as 4.5 days. Examination of

236 the time series of aerosol properties also reveals that the changes in concentrations associated

237 with air mass transitions are much greater than those occurring on a diurnal cycle. The

238 durations of influence for different air masses and the magnitude of the associated

239 concentration changes supports our focus on air mass origin in this analysis.

240 4.2. Meteorology

241 Surface level meteorological data were collected at one-minute time resolution using

242 a weather transmitter (Vaisala model WXT510) that was collocated with the understory

243 inlets. The study period was generally cooler and wetter than normal summertime conditions

244 at UMBS. The mean temperature during the study was $16.9 \pm 4.0^{\circ} \mathrm{C}$ (mean \pm one standard

245 deviation; data are not normally distributed), which was $2-3{ }^{\circ} \mathrm{C}$ cooler than the 2008 and

2462010 summers (Toma and Bertman, 2012). The study period also had higher than usual RH,

247 averaging $74.5 \pm 17.5 \%$. While measuring within the understory influenced these temperature

248 and RH measurements, the cool, damp conditions were not isolated to that location. It was

249 cloudy or foggy at the site on $62 \%$ of the days during CABINEX, which was an unusually

250 high fraction (Bryan et al., 2012). 
Mean value maps for temperature and RH are presented in Figure S1. As might be

252

253

254

255

256

257

258

259

260

261

262

263

264 expected, temperatures were typically cooler when the site was impacted by more northerly air masses. In contrast, the RH mean value map shows that air from the south and east is somewhat more humid than air reaching the site from the north. These qualitative results are supported by the source-region means for the clean and anthropogenically impacted air masses (Table 1). As suggested by the maps, air from the clean region was cooler $(15.8 \pm 4.1$ ${ }^{\circ} \mathrm{C}$ versus $\left.18.5 \pm 3.2{ }^{\circ} \mathrm{C}\right)$ and drier $(72 \pm 19 \%$ versus $80 \pm 13 \%)$ than air from the anthropogenically-impacted results. To test the significance of these results, we compared the clean and anthropogenically-impacted sample populations using Student's t-tests. Both results are significant at $\mathrm{p}<0.01$. Thus, despite the presumed influence of understory processes on local conditions, the temperature and humidity were still influenced by the air mass origin region in a statistically significant way. The results are noteworthy, because any increased aerosol scattering in this region associated with intermittent anthropogenic influence may be further enhanced by the higher mean RH in air masses from these regions.

Table 1: Mean values of aerosol and trace gas properties for air originating from clean and anthropogenically-impacted regions. Data are reported \pm one standard deviation, but the data are not normally distributed. Shaded rows indicate that the difference between the clean and anthropogenically-impacted mean values are statistically significant $(\mathrm{p}<0.01)$

\begin{tabular}{|c|ccc}
\hline Parameter & Clean Air Masses & $\begin{array}{c}\text { Anthropogenically- } \\
\text { Impacted Air Masses }\end{array}$ & Overall \\
\hline$N_{\text {total }}\left(\mathrm{cm}^{-3}\right)$ & $1,630 \pm 1,280$ & $3,020 \pm 1,280$ & $2,200 \pm 1,530$ \\
$V_{\text {total }}\left(\mu \mathrm{m}^{3} \mathrm{~cm}^{-3}\right)$ & $1.9 \pm 1.3$ & $4.8 \pm 1.8$ & $2.9 \pm 2.0$ \\
Median Diameter $(\mathrm{nm})$ & $73 \pm 21$ & $84 \pm 18$ & $76 \pm 20$ \\
Water Soluble Organics & $4.3 \pm 5.3$ & $5.8 \pm 4.9$ & $5.2 \pm 6.1$ \\
$\left(\mu \mathrm{g} \mathrm{m}^{-3}\right)$ & $0.6 \pm 1.1$ & $3.8 \pm 3.0$ & $1.8 \pm 2.5$ \\
Sulfate $\left(\mu \mathrm{g} \mathrm{m}^{-3}\right)$ & Insufficient Data & Insufficient Data & $0.3 \pm 0.3$ \\
Nitrate $\left(\mu \mathrm{g} \mathrm{m}^{-3}\right)$ & Insufficient Data & $0.6 \pm 0.4$ & $0.5 \pm 0.5$ \\
Ammonium $\left(\mu \mathrm{g} \mathrm{m}^{-3}\right)$ & $420 \pm 250$ & $1,380 \pm 610$ & $750 \pm 580$ \\
$N_{\mathrm{CCN}} @ s=0.3 \%$ & $0.18 \pm 0.08$ & $0.24 \pm 0.12$ & $0.20 \pm 0.09$ \\
$\kappa$ @ $s=0.3 \%$ & $0.32 \pm 0.18$ & $0.47 \pm 0.17$ & $0.37 \pm 0.18$ \\
Activated Fraction & $0.52 \pm 0.58$ & $0.96 \pm 0.58$ & $0.68 \pm 0.63$ \\
NO ${ }_{\mathrm{x}}(\mathrm{ppbv})$ & $0.06 \pm 0.08$ & $0.14 \pm 0.18$ & $0.09 \pm 0.12$ \\
Toluene (ppbv) & $15.8 \pm 4.1$ & $18.5 \pm 3.2$ & $16.9 \pm 4.0$ \\
Temperature $\left({ }^{\circ} \mathrm{C}\right)$ & $72 \pm 19$ & $80 \pm 13$ & $74.5 \pm 17.5$ \\
Relative Humidity $(\%)$ & & &
\end{tabular}

\subsection{Aerosol Size Distribution and Composition}

The time series of the particle number size distribution and the total particle concentration $\left(N_{\text {total }}\right)$ are shown in Figure 2. Throughout most of the campaign, the size 
273 distribution was unimodal. The temporal mean of the hourly median particle diameter was 76

$274 \pm 20 \mathrm{~nm}$, while the mean particle number concentration was 2,200 $\pm 1,530 \mathrm{~cm}^{-3}$. Despite the 275 dominance of small particles at the PROPHET site, only two new particle formation (NPF)

276 events were clearly observed during the experiment, on 16 July and 2 August. These events 277 were identified and analyzed in detail by Kanawade et al. (2011) and will not be discussed 278 further here.
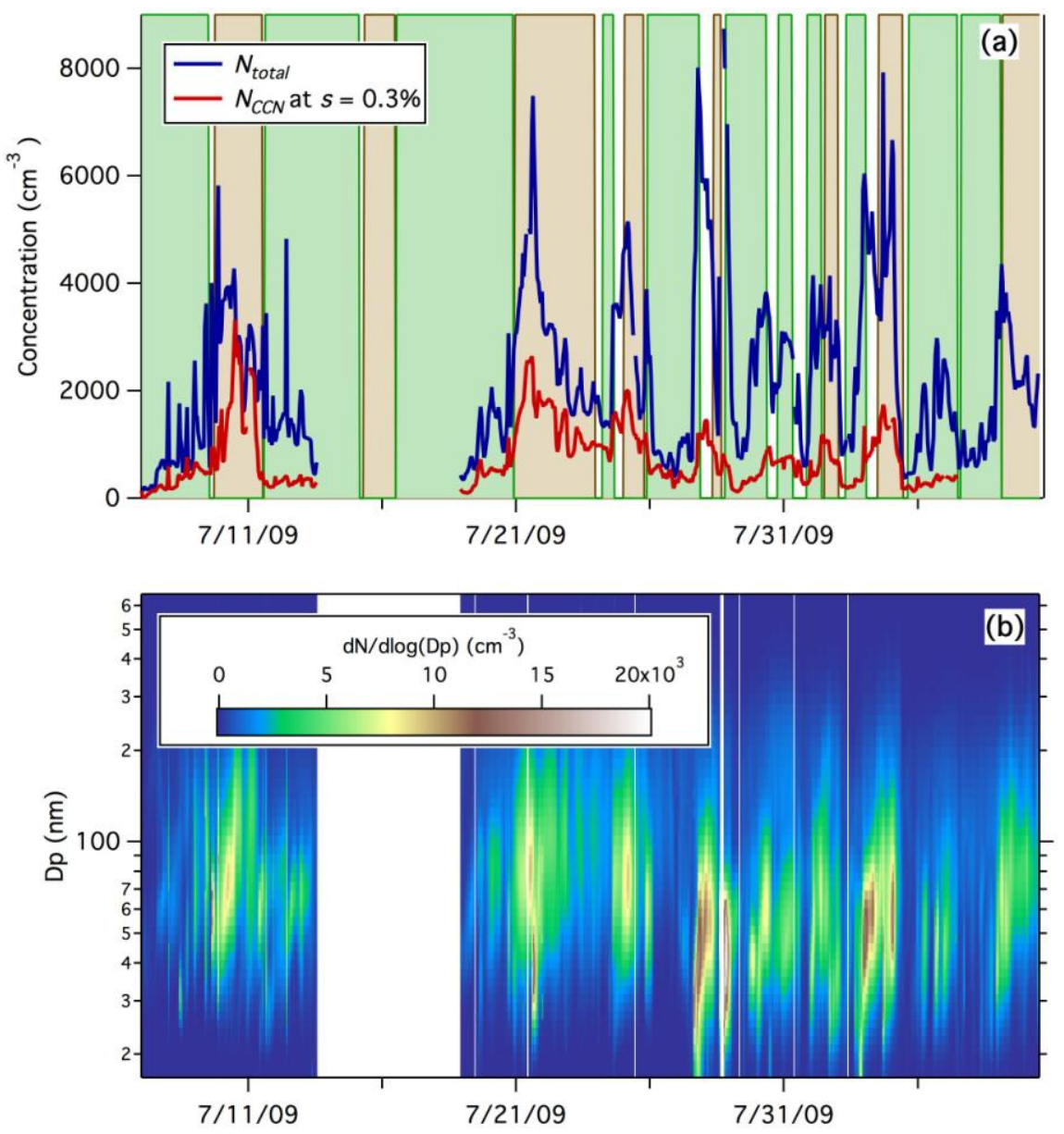

280 Figure 2: Time series of aerosol properties during CABINEX. Top panel shows the total 281 particle concentration $\left(N_{\text {total }}\right)$ and $\mathrm{CCN}$ concentration at supersaturation $(s)=0.3 \%$. Bottom 282 panel shows the particle size distribution $\left(\mathrm{d} N / \mathrm{d} \log \left(D_{p}\right)\right)$. Shading in the top panel indicates 283 periods when air masses originated from clean (green) and anthropogenically-impacted 284 (brown) regions.

The water-soluble composition was generally dominated by organic material with periods of strong sulfate loadings as well. The average concentrations of water soluble organics, $\mathrm{SO}_{4}{ }^{2-}, \mathrm{NO}_{3}{ }^{-}$, and $\mathrm{NH}_{4}{ }^{+}$during the study were $5.2 \pm 6.1 \mu \mathrm{g} \mathrm{m}^{-3}, 1.8 \pm 2.5 \mu \mathrm{g} \mathrm{m}^{-3}, 0.3$ 
$289 \pm 0.3 \mu \mathrm{g} \mathrm{m}^{-3}$, and $0.5 \pm 0.5 \mu \mathrm{g} \mathrm{m}^{-3}$, respectively. The large standard deviations relative to the means are due to the high temporal variability in aerosol concentrations. The crustal elements monitored $\left(\mathrm{Ca}^{2+}, \mathrm{Mg}^{2+}, \mathrm{K}^{+}, \mathrm{Na}^{+}\right.$and $\left.\mathrm{Cl}^{-}\right)$were nearly always below instrumental detection

292 limits.

The observed $\mathrm{NH}_{4}{ }^{+}$to $\mathrm{SO}_{4}{ }^{2-}$ ratio in the water-soluble $\mathrm{PM}_{2.5}$ shows that the sulfate observed during CABINEX was rarely neutralized and thus that the site is ammonia-limited. The results of this stoichiometric analysis are shown in Figure 3. Full neutralization of sulfate to $\left(\mathrm{NH}_{4}\right)_{2} \mathrm{SO}_{4}$ would result in data falling on the 2:1 line in the figure, and partial neutralization to $\mathrm{NH}_{4} \mathrm{HSO}_{4}$ would lead to data falling on the 1:1 line. During CABINEX, we observed an $\mathrm{NH}_{4}{ }^{+}$to $\mathrm{SO}_{4}{ }^{2-}$ ratio of $0.86\left(\mathrm{r}^{2}=0.83\right)$, indicating that $\mathrm{NH}_{4} \mathrm{HSO}_{4}$ was the major constituent in most cases. In some cases the observed ratio was greater than one, indicating the presence of some $\mathrm{SO}_{4}{ }^{2-}$, but in many more cases the ratio was less than one, indicating that unneutralized sulfuric acid was also frequently present in the condensed phase. The results make clear that acidic aerosol conditions are common in this region.

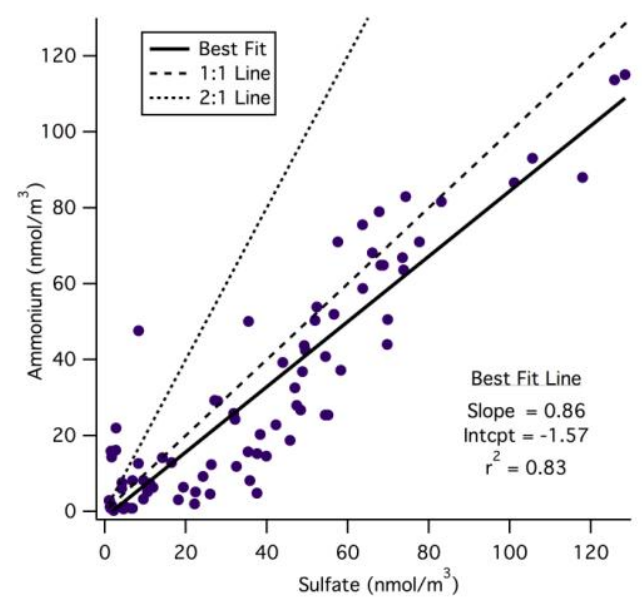

Figure 3: Scatter plot showing the molar ratio between ammonium and sulfate ions in the water-soluble $\mathrm{PM}_{2.5}$. The comparison is based on the two-hour average ion concentrations, including only instances where both sulfate and ammonium were above detection limits $(n=$ 83). The slope between these two ions indicates that sulfate was only partially neutralized by ammonium. The regression intercept is within one standard deviation of the origin. Also shown in the plot are the 1:1 line and the 2:1 lines for comparison. 
314 reveal the primary driver for this variability (Figure 4). They show that aerosol properties

315 during CABINEX were clearly influenced by the air masses' regions of origin. On average,

316 air originating from northerly regions appears to have roughly half the number of total

317 particles (Figure 4a) compared with air originating from the south. Northerly air masses also

318 exhibited dry aerosol volumes much smaller than those observed during periods when air

319 arrived at PROPHET from the south (Figure 4b). This increased aerosol volume implies a

320 similar increase in aerosol mass in anthropogenically-impacted air masses.
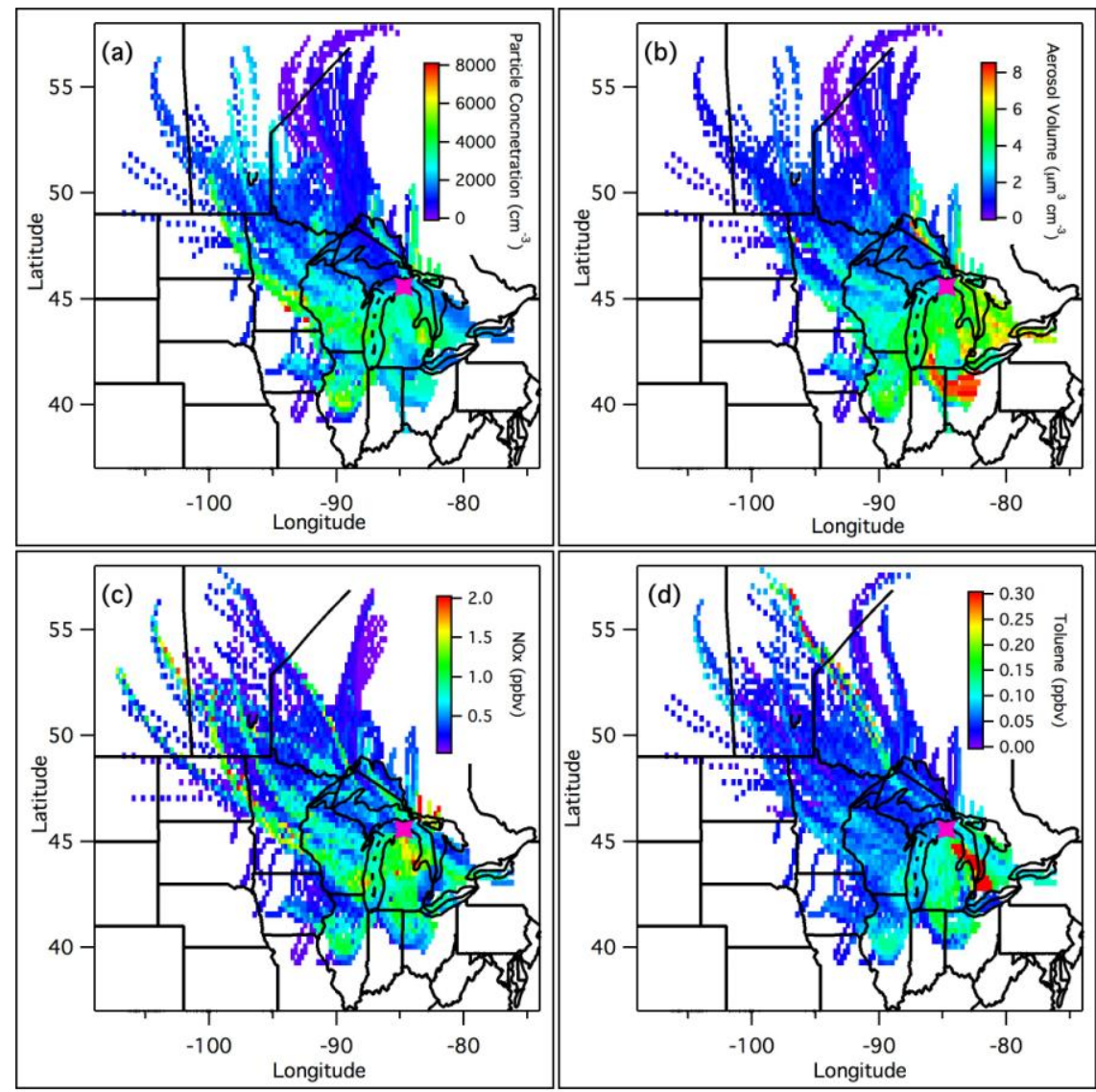

322 Figure 4: Mean value maps for (a) aerosol number concentration; (b) dry aerosol volume; (c) $\mathrm{NO}_{\mathrm{x}}$; and (d) toluene derived using air mass trajectory analysis. Pink crosses indicate the measurement site.

To better quantify these apparent effects of air mass origin on the aerosol at PROPHET, we calculated the source-region averages for these properties for clean and anthropogenically-impacted air masses. The results of this analysis are presented in Table 1.

329 The mean particle number concentration for clean regions was $1,630 \pm 1,280 \mathrm{~cm}^{-3}$, while for 330 anthropogenically-impacted regions it was $3,020 \pm 1,280 \mathrm{~cm}^{-3}$. Mean volumes were $1.9 \pm 1.3$ $331 \mu \mathrm{m}^{3} \mathrm{~cm}^{-3}$ and $4.8 \pm 1.8 \mu \mathrm{m}^{3} \mathrm{~cm}^{-3}$ for the clean and anthropogenically-impacted regions, 
332

333

334

335

336

337

338

339

340

341

342

343

344

345

346

347

348

349

350

351

352

353

354

355

356

357

respectively. Thus, relative to the clean air masses, the anthropogenically-impacted air masses had on average a $85 \%$ greater particle number concentration and $150 \%$ more aerosol volume. The average median diameter was $11 \mathrm{~nm}$ greater in the anthropogenically-impacted air relative to clean ( $84 \pm 18 \mathrm{~nm}$ and $73 \pm 21 \mathrm{~nm}$, respectively). Based on Student's t-tests, these differences are each significant at $\mathrm{p}<0.01$.
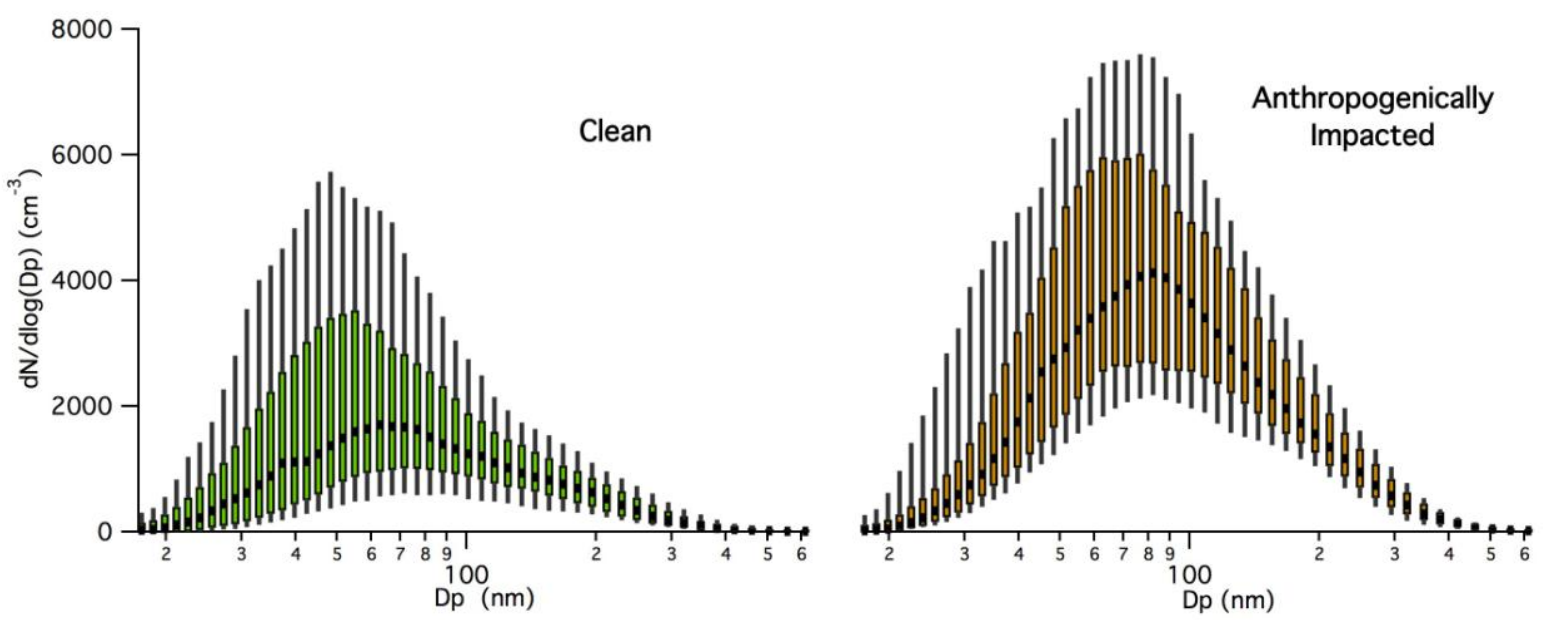

Figure 5: Box plots of the particle size distributions for air masses originating from the clean (left) and anthropogenically-impacted (right) regions. In each plot, median values are indicated by the central black marker, the $25-75^{\text {th }}$ percentiles are denoted by the colored boxes, and the $10-90^{\text {th }}$ percentiles are denoted by grey whiskers. The plots share a common yaxis. The plots are based on the hourly-averaged particle size distribution data when air was from clean $(n=383)$ and anthropogenically impacted $(n=168)$ regions. The region of origin was determined based on the bearing from the observation point to the location of the air mass 24 hours prior to observation, using back trajectory analysis as described in the text.

The differences in aerosol populations between the clean and anthropogenicallyimpacted air masses are apparent when examining the particle size distributions for each source region (Figure 5). The distribution for anthropogenically-impacted air indicates greater concentrations across the size range, a broader accumulation mode, and a shift toward larger particles. This is a fairly typical distribution for anthropogenically-impacted air after atmospheric aging, where condensational growth and cloud processing lead to a larger, more stable accumulation mode. Differences in the water-soluble $\mathrm{PM}_{2.5}$ composition between the two source regions are less strong. Much more sulfate was present in air arriving from the anthropogenically-impacted region, more than five times the levels observed from the clean region (Table 1). This result was statistically significant $(\mathrm{p}<0.01)$, and is consistent with the intermittent influence of large industrial sources of $\mathrm{SO}_{2}$ from coal-fired power plants in 
358

359

360

361

362

363

364

365

366

367

368

369

370

371

372

373

374

375

376

377

378

379

380

381

382

383

384

385

386

387

388

389

390

Indiana, Ohio, and southern Michigan. It is also consistent with the wind-direction dependence for sulfate reported by Delia in her dissertation work (2004). On the other hand, the observed differences in water-soluble organic carbon were not statistically robust, and because of the large proportion of samples below instrument detection limits we are unable to report source-region averaged values for nitrate or ammonium.

For comparison with the aerosol mean value maps and the earlier analysis of Cooper et al. (2001), we also examined mean value maps for nitrogen oxides $\left(\mathrm{NO}_{\mathrm{x}}\right)$ and toluene, trace gases typically associated with primary anthropogenic emissions. $\mathrm{NO}_{\mathrm{x}}$ was measured during CABINEX using a research-grade chemiluminescence $\mathrm{NO} / \mathrm{NO}_{2} / \mathrm{NO}_{\mathrm{y}}$ analyzer (Air Quality Designs) (Wallace et al., 2012). Toluene and other organic trace gases were measured using a Proton Transfer Reaction Mass Spectrometer (PTRMS, Ionicon Analitik) (Jobson and McCoskey, 2010). The spatial patterns for $\mathrm{NO}_{\mathrm{x}}$ (Figure 3c) and toluene (Figure 3d) are similar to those observed for the aerosol properties, with higher concentrations linked with the anthropogenically-impacted regions to the east, south, and southwest and lower concentrations associated with the clean regions to the west and north. Comparing the sourceregion averages, there was $67 \%$ more $\mathrm{NO}_{\mathrm{x}}$ and $133 \%$ more toluene in the anthropogenicallyimpacted air masses relative to clean ones. The variability was large but the differences in mean values were significant at $\mathrm{p}<0.01$ (Table 1). The source-region averaged $\mathrm{NO}_{\mathrm{x}}$ concentrations are similar to those presented graphically by Cooper et al. (2001), but the earlier study does not include mean concentrations and so a quantitative comparison is not possible. Given the similarity in the spatial patterns between the anthropogenically-linked trace gases and the aerosol properties, we can conclude that the higher aerosol number and volume concentrations, the larger particle sizes, and the increased presence of aerosol sulfate are all the result of anthropogenic emissions impacting the PROPHET site.

\subsection{Aerosol Hygroscopicity}

$\mathrm{CCN}$ number concentration at five supersaturations was measured during CABINEXat $0.3 \%, 0.4 \%, 0.5 \%, 0.6 \%$, and $0.8 \%$. The time series for the $\mathrm{CCN}$ concentration at $s=0.3 \%$ is shown in Figure 1, and a statistical summary of the CCN observations is presented in the supplementary material (Table S1). CCN number concentrations tracked well temporally with the total number concentration $\left(N_{\text {total }}\right)$, with the activation ratio $\left(N_{\mathrm{CCN}} / N_{\text {total }}\right)$ averaging between $0.33(s=0.3 \%)$ and $0.63(s=0.8 \%)$. Table S1 also summarizes the CCN activityderived $\kappa$ hygroscopicity parameters for each measured supersaturation. The mean value of $\kappa$ for $s=0.3 \%$ averaged $0.20 \pm 0.09$, and the mean at $s=0.8 \%$ was $0.13 \pm 0.08$. These results 
391

392

393

394

395

396

397

398

399

400

401

402

403

404

405

406

407

408

409

410

411

412

413

414

415

416

417

are similar to what have previously been reported for biogenically-derived secondary organic aerosol at forest sites in North America and Europe, with values varying between 0.06 and 0.22 (e.g., Cerully et al., 2011; Levin et al., 2012; Pierce et al., 2012; Sihto et al., 2011). The analysis also revealed that hygroscopicities at higher supersaturations were consistently less than at lower supersaturations. This variability was less than the temporal variation for any given supersaturation, but the pattern persisted across the range of measured supersaturations throughout the entire study. The pattern, similar to one observed previously by Levin et al. (2012), suggests that smaller particles were consistently less hygroscopic than larger ones.

These results imply that biogenic SOA becomes more hygroscopic as it ages in the atmosphere, since larger particles would be expected to have more aged organic material.

Such a conclusion is consistent with the previous studies that reveal that laboratory-generated SOA from known biogenic precursors have lower $\kappa$-values (0.009 to 0.033) (Petters and Kreidenweis, 2007; VanReken et al., 2005) than ambient values measured in this or previous studies.

As with the other aerosol properties, $\mathrm{CCN}$ concentrations and hygroscopicities also exhibited distinct differences based on the origin of the air masses reaching the measurement site. $\mathrm{CCN}$ were much more numerous in the anthropogenically-impacted air masses, on average more than three times the concentration observed in clean air (at $s=0.3 \%$, Table 1 ). The increase in $N_{\mathrm{CCN}}$ between clean and anthropogenically-impacted source regions was greater than for $N_{\text {total }}$, leading to an increase in the activated fraction as well, from $32 \pm 18 \%$ to $47 \pm 17 \%$, on average, at $s=0.3 \%$. The increased average particle size in anthropogenically-impacted air caused much of this difference, but composition played a role as well; at $s=0.3 \%$ the average $\kappa$-values for the clean and anthropogenically-impacted air masses were $0.18 \pm 0.08$ to $0.24 \pm 0.17$, respectively. Each of these results was statistically significant $(\mathrm{p}<0.01)$. These results are consistent with the increased influence of more soluble inorganic material in the anthropogenically-influenced aerosol relative to the organics-dominated clean aerosol.

\section{Conclusions}

In this paper we have presented a detailed characterization of aerosols at the PROPHET site at UMBS, based on measurements collected during the 2009 CABINEX experiment. The average properties were fairly typical of a remote continental location, but there was a strong dependence on air mass direction of origin for most parameters. For $60 \%$ 
423

424

425

426

427

428

429

430

431

432

433

434

435

436

437

438

439

440

441

442

443

444

445

446

447

448

449

450

451

452

453

454

of the study period, air originated from relatively pristine areas to the north and west. These periods were characterized by lower aerosol loadings, with smaller particle number concentrations, lower volume concentrations, reduced median diameters, and lower watersoluble mass concentrations. These results are consistent with these periods being dominated by the presence of biogenic SOA. In contrast, air masses originating from the urbanized regions to the east, south, and southwest of PROPHET (29\% of the study period) more numerous and larger particles on average. Volume concentrations were more than twice as high, and sulfate loadings were on average six times higher in anthropogenically-impacted air. These results are consistent with the expected impacts of aged anthropogenic emissions reaching the site. The aerosol hygroscopic properties were similar to what has been observed at other forested sites dominated by biogenic SOA in the United States and Europe, and followed the same trends with respect to air mass origin as the other aerosol properties. There were significantly more $\mathrm{CCN}$ in anthropogenically-impacted air masses, with somewhat greater hygroscopicity, consistent with the higher observed particle concentrations and sulfate loadings. These large shifts in aerosol properties were not ground in a single severe event the study period included 15 transitions from clean to anthropogenically-impacted conditions, with individual instances lasting from 7 hours to 4.5 days.

The detailed location-specific data and analysis reported here will be a useful resource for comparison with regional models and satellite observations and is expected to serve as a foundation for future investigations of aerosol and biosphere-atmosphere interactions at the PROPHET site. The region's strong variability in atmospheric chemical properties based on air mass origin have the potential to impact ecosystem functions, including water distribution, radiative transfer, and biogenic VOC emssions. These interactions have been proposed as a source of bidirectional feedbacks between the biosphere and atmosphere that may be amplified in response to a changing climate. Detailed study of these phenomena is merited, and those investigations will benefit from the comparitive analysis presented here.

\section{Acknowledgments}

The authors gratefully acknowledge the NOAA Air Resources Laboratory (ARL) for the provision of the HYSPLIT transport and dispersion model and/or READY website (http://www.arl.noaa.gov/ready.php) used in this publication. Analyses in this paper were produced with the Giovanni online data system, developed and maintained by the NASA GES DISC. The authors thank Farren Herron-Thorpe for his assistance in accessing OMI 
data. Funding for this work was provided by NSF award AGS-0904214 and a U.S.

Department of Energy Early Career Research Program award (\# SC0003899). Data are available from the corresponding author upon request.

\section{References}

Ashbaugh, L.L., Malm, W.C., Sadeh, W.Z., 1985. A residence time probability analysis of sulfur concentrations at grand Canyon National Park. Atmos. Env. 19, 1263-1270. doi:10.1016/0004-6981(85)90256-2

Bergen, K.M., Dronova, I., 2007. Observing succession on aspen-dominated landscapes using a remote sensing-ecosystem approach. Landscape Ecol 22, 1395-1410. doi:10.1007/s10980-007-9119-1

Bryan, A.M., Bertman, S.B., Carroll, M.A., Dusanter, S., Edwards, G.D., Forkel, R., Griffith, S., Guenther, A.B., Hansen, R.F., Helmig, D., Jobson, B.T., Keutsch, F.N., Lefer, B.L., Pressley, S.N., Shepson, P.B., Stevens, P.S., Steiner, A.L., 2012. In-canopy gasphase chemistry during CABINEX 2009: sensitivity of a 1-D canopy model to vertical mixing and isoprene chemistry. Atmos. Chem. Phys. 12, 8829-8849. doi:10.5194/acp-12-8829-2012

Carroll, M.A., Bertman, S.B., Shepson, P.B., 2001. Overview of the Program for Research on Oxidants: PHotochemistry, Emissions, and Transport (PROPHET) summer 1998 measurements intensive. J. Geophys. Res. 106, 24275-24,288. doi:10.1029/2001JD900189

Carslaw, K.S., Boucher, O., Spracklen, D.V., Mann, G.W., Rae, J.G.L., Woodward, S., Kulmala, M., 2010. A review of natural aerosol interactions and feedbacks within the Earth system. Atmos. Chem. Phys. 10, 1701-1737.

Cerully, K.M., Raatikainen, T., Lance, S., Tkacik, D., Tiitta, P., Petäjä, T., Ehn, M., Kulmala, M., Worsnop, D.R., Laaksonen, A., Smith, J.N., Nenes, A., 2011. Aerosol hygroscopicity and CCN activation kinetics in a boreal forest environment during the 2007 EUCAARI campaign. Atmos. Chem. Phys. 11, 12369-12386. doi:10.5194/acp11-12369-2011

Chung, S.H., Basarab, B.M., VanReken, T.M., 2011. Regional impacts of ultrafine particle emissions from the surface of the Great Lakes. Atmos. Chem. Phys. 11, 1260112615. doi:10.5194/acp-11-12601-2011

Cooper, O.R., Moody, J.L., Thornberry, T.D., Town, M.S., Carroll, M.A., 2001. PROPHET 1998 meteorological overview and air-mass classification. J. Geophys. Res. 106, 24289-24299. doi:10.1029/2000JD900409

Delia, A.E., 2004. Real-Time Measurements of Non-Refractory Particle Composition and Interactions at Rural and Semi-Rural Sites (Ph.D. Dissertation). University of Colorado.

Draxler, R.R., Rolph, G.D., 2013. HYSPLIT (HYbrid Single-Particle Lagrangian Integrated Trajectory) Model access via NOAA ARL READY Website (http://ready.arl.noaa.gov/HYSPLIT.php). NOAA Air Resources Laboratory, Silver Spring, MD.

Fowler, D., Pilegaard, K., Sutton, M.A., Ambus, P., Raivonen, M., Duyzer, J., Simpson, D., Fagerli, H., Fuzzi, S., Schjoerring, J.K., Granier, C., Neftel, A., Isaksen, I.S.A., Laj, P., Maione, M., Monks, P.S., Burkhardt, J., Daemmgen, U., Neirynck, J., Personne, E., Wichink-Kruit, R., Butterbach-Bahl, K., Flechard, C., Tuovinen, J.P., Coyle, M., 
Gerosa, G., Loubet, B., Altimir, N., Gruenhage, L., Ammann, C., Cieslik, S., Paoletti, E., Mikkelsen, T.N., Ro-Poulsen, H., Cellier, P., Cape, J.N., Horvath, L., Loreto, F., Niinemets, U., Palmer, P.I., Rinne, J., Misztal, P., Nemitz, E., Nilsson, D., Pryor, S., Gallagher, M.W., Vesala, T., Skiba, U., Brueggemann, N., Zechmeister-Boltenstern, S., Williams, J., O’Dowd, C., Facchini, M.C., de Leeuw, G., Flossman, A., Chaumerliac, N., Erisman, J.W., 2009. Atmospheric composition change: Ecosystems-Atmosphere interactions. Atmos. Environ. 43, 5193-5267. doi:10.1016/j.atmosenv.2009.07.068

Guenther, A., Karl, T., Harley, P., Wiedinmyer, C., Palmer, P.I., Geron, C., 2006. Estimates of global terrestrial isoprene emissions using MEGAN (Model of Emissions of Gases and Aerosols from Nature). Atmos. Chem. Phys. 6, 3181-3210.

Jeong, C.-H., Evans, G.J., McGuire, M.L., Chang, R.Y.-W., Abbatt, J.P.D., Zeromskiene, K., Mozurkewich, M., Li, S.-M., Leaitch, W.R., 2010. Particle formation and growth at five rural and urban sites. Atmos. Chem. Phys. 10, 7979-7995. doi:10.5194/acp-107979-2010

Jobson, B.T., McCoskey, J.K., 2010. Sample drying to improve HCHO measurements by PTR-MS instruments: laboratory and field measurements. Atmospheric 10, 18211835. doi:10.5194/acp-10-1821-2010

Kabashnikov, V.P., Chaikovsky, A.P., Kucsera, T.L., Metelskaya, N.S., 2011. Estimated accuracy of three common trajectory statistical methods. Atmos. Environ. 45, 54255430. doi:10.1016/j.atmosenv.2011.07.006

Kanawade, V.P., Jobson, B.T., Guenther, A.B., Erupe, M.E., Pressley, S.N., Tripathi, S.N., Lee, S.-H., 2011. Isoprene suppression of new particle formation in a mixed deciduous forest. Atmos. Chem. Phys. 11, 6013-6027. doi:10.5194/acp-11-60132011

Kaufman, Y.J., Koren, I., Remer, L.A., Rosenfeld, D., Rudich, Y., 2005. The effect of smoke, dust, and pollution aerosol on shallow cloud development over the Atlantic Ocean. PNAS 102, 11207-11212. doi:10.1073/pnas.0505191102

Levin, E.J.T., Prenni, A.J., Petters, M.D., Kreidenweis, S.M., Sullvan, R.C., Atwood, S.A., Ortega, J., DeMott, P.J., Smith, J.N., 2012. An annual cycle of size-resolved aerosol hygroscopicity at a forested site in Colorado. J. Geophys. Res. Atmos. 117. doi:10.1029/2011JD016854

Mwaniki, G.R., Rosenkrance, C., Wallace, H.W., Jobson, B.T., Erickson, M.H., Lamb, B.K., Zalakeviciute, R., VanReken, T.M., 2014. Factors Contributing to Elevated Concentrations of PM2.5 during Wintertime near Boise, Idaho. Atmospheric Pollution Research 14, 96-103. doi:10.5094/APR.2014.012

Orsini, D.A., Ma, Y.L., Sullivan, A., Sierau, B., Baumann, K., Weber, R.J., 2003. Refinements to the particle-into-liquid sampler (PILS) for ground and airborne measurements of water soluble aerosol composition. Atmos. Environ. 37, 1243-1259. doi:10.1016/S1352-2310(02)01015-4

Petters, M.D., Kreidenweis, S.M., 2007. A single parameter representation of hygroscopic growth and cloud condensation nucleus activity. Atmos. Chem. Phys. 7, 1961-1971.

Pierce, J.R., Leaitch, W.R., Liggio, J., Westervelt, D.M., Wainwright, C.D., Abbatt, J.P.D., Ahlm, L., Al-Basheer, W., Cziczo, D.J., Hayden, K.L., Lee, A.K.Y., Li, S.-M., Russell, L.M., Sjostedt, S.J., Strawbridge, K.B., Travis, M., Vlasenko, A., Wentzell, J.J.B., Wiebe, H.A., Wong, J.P.S., Macdonald, A.M., 2012. Nucleation and condensational growth to CCN sizes during a sustained pristine biogenic SOA event in a forested mountain valley. Atmos. Chem. Phys. 12, 3147-3163. doi:10.5194/acp12-3147-2012 
Pressley, S., Lamb, B., Westberg, H., Flaherty, J., Chen, J., Vogel, C., 2005. Long-term isoprene flux measurements above a northern hardwood forest. J. Geophys. Res. 110, D07301. doi:10.1029/2004JD005523

Roberts, G.C., Day, D.A., Russell, L.M., Dunlea, E.J., Jimenez, J.L., Tomlinson, J.M., Collins, D.R., Shinozuka, Y., Clarke, A.D., 2010. Characterization of particle cloud droplet activity and composition in the free troposphere and the boundary layer during INTEX-B. Atmos. Chem. Phys. 10, 6627-6644. doi:10.5194/acp-10-6627-2010

Roberts, G.C., Nenes, A., 2005. A continuous-flow streamwise thermal-gradient CCN chamber for atmospheric measurements. Aerosol Sci. Technol. 39, 206-221. doi:10.1080/027868290913988

Robinson, N.H., Newton, H.M., Allan, J.D., Irwin, M., Hamilton, J.F., Flynn, M., Bower, K.N., Williams, P.I., Mills, G., Reeves, C.E., McFiggans, G., Coe, H., 2011. Source attribution of Bornean air masses by back trajectory analysis during the OP3 project. Atmos. Chem. Phys. 11, 9605-9630. doi:10.5194/acp-11-9605-2011

Seinfeld, J.H., Pandis, S.N., 2006. Atmospheric Chemistry and Physics: From Air Pollution to Climate Change, 2nd ed. Wiley-Interscience, Hoboken, New Jersey.

Sheesley, R.J., Schauer, J.J., Bean, E., Kenski, D., 2004. Trends in Secondary Organic Aerosol at a Remote Site in Michigan's Upper Peninsula. Environ. Sci. Technol. 38, 6491-6500. doi:10.1021/es049104q

Sihto, S.-L., Mikkilä, J., Vanhanen, J., Ehn, M., Liao, L., Lehtipalo, K., Aalto, P.P., Duplissy, J., Petäjä, T., Kerminen, V.-M., Boy, M., Kulmala, M., 2011. Seasonal variation of CCN concentrations and aerosol activation properties in boreal forest. Atmos. Chem. Phys. 11, 13269-13285. doi:10.5194/acp-11-13269-2011

Slade, J.H., VanReken, T.M., Mwaniki, G.R., Bertman, S., Stirm, B., Shepson, P.B., 2010. Aerosol production from the surface of the Great Lakes. Geophys. Res. Lett. 37, L18807. doi:10.1029/2010GL043852

Slowik, J.G., Stroud, C., Bottenheim, J.W., Brickell, P.C., Chang, R.Y.-W., Liggio, J., Makar, P.A., Martin, R.V., Moran, M.D., Shantz, N.C., Sjostedt, S.J., van Donkelaar, A., Vlasenko, A., Wiebe, H.A., Xia, A.G., Zhang, J., Leaitch, W.R., Abbatt, J.P.D., 2010. Characterization of a large biogenic secondary organic aerosol event from eastern Canadian forests. Atmos. Chem. Phys. 10, 2825-2845. doi:10.5194/acp-102825-2010

Steiner, A.L., Mermelstein, D., Cheng, S.J., Twine, T.E., Oliphant, A., 2013. Observed impact of atmospheric aerosols on the surface energy budget. Earth Interactions 130724124047002. doi:10.1175/2013EI000523.1

Steiner, A.L., Pressley, S.N., Botros, A., Jones, E., Chung, S.H., Edburg, S.L., 2011. Analysis of coherent structures and atmosphere-canopy coupling strength during the CABINEX field campaign. Atmos. Chem. Phys. 11, 11921-11936. doi:10.5194/acp11-11921-2011

Sullivan, A.P., Weber, R.J., Clements, A.L., Turner, J.R., Bae, M.S., Schauer, J.J., 2004. A method for on-line measurement of water-soluble organic carbon in ambient aerosol particles: Results from an urban site. Geophys. Res. Lett. 31. doi:10.1029/2004GL019681

Toma, S., Bertman, S., 2012. The atmospheric potential of biogenic volatile organic compounds from needles of white pine (Pinus strobus) in Northern Michigan. Atmos. Chem. Phys. 12, 2245-2252. doi:10.5194/acp-12-2245-2012

Tsigaridis, K., Kanakidou, M., 2007. Secondary organic aerosol importance in the future atmosphere. Atmos. Environ. 41, 4682-4692. doi:10.1016/j.atmosenv.2007.03.045 
VanReken, T., Ng, N., Flagan, R., Seinfeld, J., 2005. Cloud condensation nucleus activation properties of biogenic secondary organic aerosol. J. Geophys. Res. Atmos. 110. doi:10.1029/2004JD005465

Wallace, H.W., Jobson, B.T., Erickson, M.H., McCoskey, J.K., VanReken, T.M., Lamb, B.K., Vaughan, J.K., Hardy, R.J., Cole, J.L., Strachan, S.M., Zhang, W., 2012. Comparison of wintertime CO to NOx ratios to MOVES and MOBILE6.2 on-road emissions inventories. Atmos. Environ. 63, 289-297. doi:10.1016/j.atmosenv.2012.08.062 